\title{
INSTABILITY OF Hh HETEROZYGOTES IN FLAX GENOTROPHS
}

\author{
J. C. MCLELLAN and A. DURRANT \\ Department of Agricultural Botany, University College of Wales, Aberystwyth
}

Received 9.iii.72

\section{SUMMARY}

The induction of large (L) and small (S) genotrophs by the environment from the plastic (Pl) genotroph is accompanied by changes in a gene determining hairy $(\mathrm{H})$ and hairless (h) septa in the capsules. $\mathrm{S}$ and $\mathrm{Pl}$ are $\mathrm{HH}$, $\mathrm{L}$ is hh. The heterozygote $\mathrm{Hh}$ is unstable and three heterozygous classes, I, II, III, are recognisable in the $F_{2}$ with approximately $30,40,50$ hairs per septum. $\mathrm{H} \rightarrow \mathrm{h}$ and $\mathrm{h} \rightarrow \mathrm{H}$ changes occur and class III $\mathrm{F}_{2} \mathrm{Hh}$ heterozygotes with the highest hair numbers give $\mathrm{H}: \mathrm{h}$ ratios in $\mathrm{F}_{3}$ of about $6: 1$. Selection of class III $\mathrm{F}_{2} \mathrm{Hh}$ heterozygotes also selects for $\mathrm{Hh}$ plants with a high $\mathrm{Hh} \rightarrow \mathrm{HH}$ potential, but only about 33 per cent. of these $F_{2}$ plants have this potential in so far as it leads to an overt and immediate change of $\mathrm{Hh} \rightarrow \mathrm{HH}$ by the next generation. In the $\mathrm{F}_{3}$ of $\mathrm{L} \times \mathrm{S}$ and $\mathrm{S} \times \mathrm{L}$ crosses a further proportion of $\mathrm{Hh}$ heterozygotes has the $\mathrm{Hh} \rightarrow \mathrm{HH}$ potential, but not in the $\mathrm{Pl} \times \mathrm{L}$ and $\mathrm{L} \times \mathrm{Pl}$ crosses. Thereafter no further changes are found. The fade-out in $\mathrm{F}_{\mathrm{g}}$ and $\mathrm{F}_{4}$ may be due to stabilisation at the locus or of associated factors, to the different environments in which the generations are grown, or because selection of class III was discontinued after $\mathbf{F}_{2}$ and all three heterozygous classes reappeared in $F_{3}$. These orderly, high-frequency changes occur in the $\mathrm{Hh}$ heterozygotes only, and are probably essentially the same as paramutation in maize.

\section{INTRODUCTION}

Heritable changes in plant weight and amount of nuclear DNA (Durrant, 1962a, 1971; Evans, Durrant and Rees, 1966; Evans, 1968) induced by growing flax plants in different environments may be accompanied by changes in a gene $\mathrm{H}-\mathrm{h}$, determining hairy-hairless septa in the capsules (Durrant and Nicholas, 1970). The variety Stormont Cirrus, a plastic genotroph ( $\mathrm{Pl})$, i.e. one in which heritable changes can be induced, has hairy septa $(\mathrm{HH})$; the small (S) stable genotroph induced from it also has hairy septa, but the large (L) stable genotroph induced from $\mathrm{Pl}$ is hairless (hh). The two alleles appear to be fairly stable in the homozygous state but heterozygotes (Hh) are not. The heterozygotes have fewer hairs per septum than the $\mathrm{HH}$ homozygote, i.e. dominance is not complete, and in the $\mathrm{F}_{2}$ the $\mathrm{Hh}$ plants can be separated into three distinct classes with mean hair numbers of 33,41 and 49 hairs per septum, compared with 60 for the HH homozygous class. They are called respectively class I, II and III heterozygotes, and presumably reflect different levels of gene activity. The hair number of one septum of one capsule is normally sufficient to classify a plant because the hair numbers of septa within a capsule, or capsules on the same plant, do not vary by more than two or three.

Plants of the three heterozygous classes give different $\mathrm{H}: \mathrm{h}$ ratios in the next generation, as shown by the summarised results in table 1 (Expt. 1 
TABLE 1

Mean hair numbers of class $I$, II and III heterozygotes in $F_{2}$ and $H: h$ ratios in $F_{3}$, in three experiments

\begin{tabular}{|c|c|c|c|c|c|c|}
\hline & Expt & & Expt & & Expt & \\
\hline & $\begin{array}{c}\mathrm{F}_{2} \\
\text { Mean hair } \\
\text { number }\end{array}$ & $\begin{array}{c}F_{3} \\
\text { Ratio } \\
(\mathrm{H} / \mathrm{h})\end{array}$ & $\begin{array}{c}\mathrm{F}_{2} \\
\text { Mean hair } \\
\text { number }\end{array}$ & $\begin{array}{c}F_{3} \\
\text { Ratio } \\
(\mathrm{H} / \mathrm{h})\end{array}$ & $\begin{array}{c}\mathrm{F}_{2} \\
\text { Mean hair } \\
\text { number }\end{array}$ & $\begin{array}{c}\mathrm{F}_{3} \\
\text { Ratio } \\
(\mathrm{H} / \mathrm{h})\end{array}$ \\
\hline $\begin{array}{c}\text { I } \\
\text { II }\end{array}$ & $\begin{array}{l}29 \cdot 8 \\
40 \cdot 4\end{array}$ & $\begin{array}{l}2 \cdot 3 \\
3 \cdot 0\end{array}$ & $\begin{array}{l}31.8 \\
40.5\end{array}$ & $\begin{array}{l}3.3 \\
3.5\end{array}$ & $\begin{array}{l}30 \cdot 9 \\
40 \cdot 1\end{array}$ & $\begin{array}{l}3.5 \\
2.7\end{array}$ \\
\hline III & 51.5 & $5 \cdot 0$ & $50 \cdot 8$ & $6 \cdot 8$ & 50.5 & 6.9 \\
\hline
\end{tabular}

and 2) of two experiments done by Durrant and Nicholas (1970). Summing over the appropriate groups of $\mathrm{F}_{3}$ families, class $\mathrm{I} \mathrm{F}_{2}$ heterozygotes with fewest hairs per septum give the lowest number of $\mathrm{H}$ plants in the $\mathrm{F}_{3}$; class III with most hairs per septum give a large excess of $\mathrm{H}$ plants, and class II an intermediate number. More information on the unstable nature of this gene has been obtained from the $\mathrm{F}_{2}$ and later generations.

\section{2. $F_{2}$ AND $F_{3}$ GENERATIONS}

Another set of $F_{3}$ families (Expt. 3) was grown from seed from independently scored $\mathrm{F}_{2}$ plants. The hair numbers of capsules taken, one from each of three plants of each of the three $\mathrm{F}_{2}$ heterozygous classes and of the $\mathrm{F}_{2} \mathrm{HH}$ homozygotes, from the four crosses $\mathrm{L} \times \mathrm{Pl}, \mathrm{Pl} \times \mathrm{L}, \mathrm{L} \times \mathrm{S}$, $\mathrm{S} \times \mathrm{L}$, are given in table $2 a$. The mean hair numbers of the three heterozygous classes and homozygous $\mathrm{HH}$ plants are close to those of Expt. 1 and 2 (table 1). The seed was sown in November 1967 in a heated greenhouse with supplementary lighting and the $F_{3}$ capsules scored in March 1968. The numbers of $\mathrm{H}$ and $\mathrm{h}$ plants in each $\mathrm{F}_{3}$ family of about 9 plants are given in table $2 b$; the position of each $\mathrm{F}_{2}$ plant and its $\mathrm{F}_{3}$ family in tables $2 a$ and $2 b$ correspond. The overall $\mathrm{F}_{3}$ ratios are entered in table 1 (Expt. 3), where class III $\mathrm{F}_{2}$ heterozygotes again give a large excess of $\mathrm{H}$ plants in $F_{3}$, and classes $I$ and II fewer $H$ plants, but here class $I$ gives more than class II.

TABLE $2 a$

Hair numbers of $F_{2}$ capsules of the three heterozygous classes $I, I I$ and III, and HH homozygotes, used in Expt. 3

\begin{tabular}{|c|c|c|c|c|c|}
\hline & $\mathrm{L} \times \mathrm{Pl}$ & $\mathrm{P} 1 \times \mathrm{L}$ & $\mathrm{L} \times \mathrm{S}$ & $\mathrm{S} \times \mathrm{L}$ & Mean \\
\hline I & $\begin{array}{l}30 \\
32 \\
34\end{array}$ & $\begin{array}{l}32 \\
30 \\
31\end{array}$ & $\begin{array}{l}27 \\
30 \\
32\end{array}$ & $\begin{array}{l}32 \\
29 \\
32\end{array}$ & $30 \cdot 9$ \\
\hline II & $\begin{array}{l}42 \\
40 \\
38\end{array}$ & $\begin{array}{l}42 \\
41 \\
40\end{array}$ & $\begin{array}{l}41 \\
44 \\
42\end{array}$ & $\begin{array}{l}44 \\
41 \\
39\end{array}$ & $40 \cdot 1$ \\
\hline III & $\begin{array}{l}52 \\
52 \\
49\end{array}$ & $\begin{array}{l}48 \\
50 \\
52\end{array}$ & $\begin{array}{l}50 \\
51 \\
51\end{array}$ & $\begin{array}{l}49 \\
50 \\
52\end{array}$ & $50 \cdot 5$ \\
\hline $\mathrm{HH}$ & $\begin{array}{l}68 \\
80 \\
64\end{array}$ & $\begin{array}{l}74 \\
73 \\
60\end{array}$ & $\begin{array}{l}62 \\
67 \\
72\end{array}$ & $\begin{array}{l}62 \\
72 \\
65\end{array}$ & 68.5 \\
\hline
\end{tabular}


The $F_{3}$ ratio of class III summed over the three experiments and four crosses is significantly different $(\mathrm{P}<0.001)$ from the combined class I and II ratios which are not significantly different themselves. Consequently, as far as the present data are concerned, the evidence for the dependence of $\mathrm{F}_{3} \mathrm{H}$ :h ratios on the $\mathrm{F}_{2}$ heterozygous class rests upon the high ratios given by class III.

In the three experiments there are altogether $38 \mathrm{~F}_{3}$ families from class III $\mathrm{F}_{2}$ heterozygotes, 16 of which contain only $\mathrm{H}$ plants, i.e. they are nonsegregating (table 3 ). The overall numbers of $\mathrm{H}$ and $\mathrm{h}$ plants given by the remaining 22 segregating families is $153 \mathrm{H}$ and $48 \mathrm{~h}$, a ratio of $\mathrm{H}: \mathrm{h}$ of $3 \cdot 18: 1$. This suggests that the high ratio given by the $38 \mathrm{~F}_{3}$ families could be because some homozygous $\mathrm{HH} \mathrm{F}_{2}$ plants have hair numbers within the $\mathrm{F}_{2}$ class III heterozygotes range and their inclusion among the class III

TABLE $2 b$

Numbers of $H$ and $h$ plants in $F_{3}$ families of Expt. 3 given by seed from capsules in table $2 a$. Positions of parent capsule and $F_{3}$ family correspond in the two tables

\begin{tabular}{|c|c|c|c|c|c|c|c|c|c|c|}
\hline & & & & & & & & & & \\
\hline & $\mathrm{H}$ & h & $\mathbf{H}$ & h & $\mathbf{H}$ & h & $\mathbf{H}$ & h & $\mathbf{H}$ & h \\
\hline & 8 & 2 & 8 & 1 & 7 & 1 & 7 & 3 & & \\
\hline I & 9 & 0 & 6 & 2 & 5 & 5 & 8 & 0 & 86 & 24 \\
\hline & 8 & 2 & 8 & 2 & 6 & 3 & 6 & 3 & & \\
\hline & 5 & 3 & 6 & 2 & 7 & 3 & 8 & 0 & & \\
\hline II & 4 & 4 & 7 & 3 & 6 & 4 & 8 & 2 & 82 & 30 \\
\hline & 6 & 4 & 10 & 0 & 7 & 3 & 8 & 2 & & \\
\hline & 8 & 1 & 8 & 2 & 7 & 2 & 9 & 0 & & \\
\hline III & 6 & 1 & 10 & 0 & 7 & 3 & 9 & 0 & 97 & 14 \\
\hline & 9 & 1 & 9 & 0 & 5 & 4 & 10 & 0 & & \\
\hline & 9 & 0 & 9 & 0 & 9 & 0 & 8 & 0 & & \\
\hline $\mathrm{HH}$ & 9 & 0 & 10 & 0 & 10 & 0 & 10 & 0 & 112 & 0 \\
\hline & 10 & 0 & 10 & 0 & 8 & 0 & 10 & 0 & & \\
\hline
\end{tabular}

plants has increased the $\mathrm{H}: \mathrm{h}$ ratio from $3: 1$ to $6: 1$ by the presence of their non-segregating $\mathrm{F}_{3}$ families.

The heterogeneity of the 38 class III $F_{3}$ families is tested in table 4 . The average number of plants per family is 8.9 , and the overall $\mathrm{H}: \mathrm{h}$ ratio is $6 \cdot 1: 1$. Rounding off to 9 plants per family and a $\mathrm{H}: \mathrm{h}$ ratio of $6: 1$ the table gives the expected frequencies, from the binomial expansion, of families with different numbers of $h$ plants per family, and the $\chi^{2}$ testing agreement of the frequencies obtained with them. The $\chi^{2}$ is significant $(\mathrm{P}<0.01)$ due to the large excess of non-segregating families and therefore the data do not agree with the hypothesis that $F_{2}$ class III heterozygotes are homogeneous in giving 6:1 ratios in $F_{3}$ families.

Another hypothesis is tested in table 4 , assuming that $F_{2}$ class III heterozygotes segregate to give 3:1 ratios in $\mathrm{F}_{3}$ families but there are included in the $\mathrm{F}_{3}$ some additional non-segregating families. Some of the class III heterozygotes are also expected to give non-segregating families, and calculations show that at least one, but not more than three, of these is expected. Accepting that two non-segregating families are due to this 
TABLE 3

Total numbers of plants, and numbers of segregating and non-segregating families, descended from class III $F_{2}$ heterozygotes. $F_{4}$ plants descended from $F_{3}$ plants in Expt. 2 only

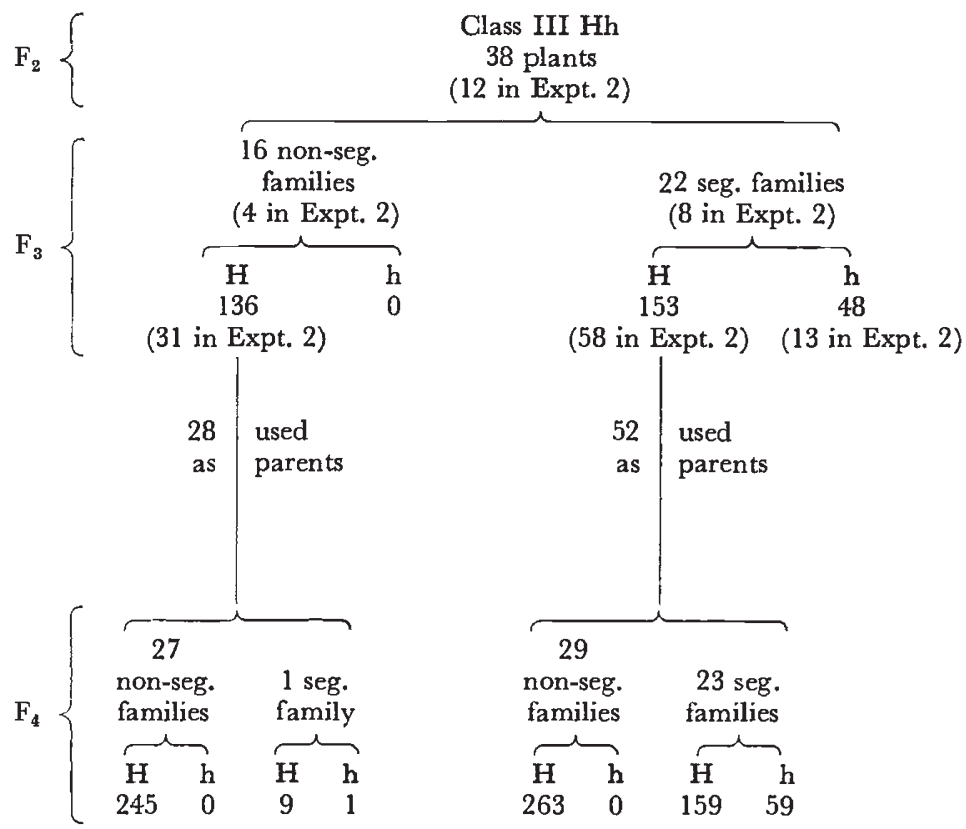

cause, 24 of the $38 \mathrm{~F}_{3}$ families may be assumed to be produced by class III $\mathrm{Hh}_{2}$ heterozygotes, the remaining 14 non-segregating families being due to other causes. The expected frequencies of the 24 families with 9 plants per family and an $\mathrm{H}: \mathrm{h}$ ratio of $3: 1$ are given in table 4 , and the $\chi^{2}$ testing agreement of the data is not significant.

The conclusion is that $F_{3}$ families assumed to have come from class III $\mathrm{F}_{2}$ heterozygotes are heterogeneous, containing one group which segregates

TABLE 4

Tests on the heterogeneity of $F_{3}$ families. The data is in agreement with a $3: 1$ ratio if 14 non-segregating families are removed

Expected numbers of families (6: 1 ratio)
Numbers obtained

Number of $h$ plants in family

\begin{tabular}{cccccc}
\hline 0 & 1 & 2 & 3 & 4 & $5+$ \\
9.5 & 14.3 & $9 \cdot 1$ & 3.7 & 0.9 & 0.5 \\
16 & 8 & 5 & 6 & 3 & 0
\end{tabular}

$$
\chi_{(5)}^{2}=15 \cdot 74 \quad \mathrm{P}<1 \text { per cent }
$$

Expected numbers of families

$$
\text { (3: } 1 \text { ratio) }
$$

Numbers obtained less 14 nonseg. families

$\begin{array}{llllll}1 \cdot 8 & 5 \cdot 4 & 7 \cdot 2 & 56 & 2 \cdot 8 & 1 \cdot 2 \\ 2 & 8 & 5 & & 3 & 0\end{array}$

$$
\chi_{(4)}^{2}=3 \cdot 18 \quad \mathrm{P}=50 \text { per cent. }
$$


in agreement with a mendelian 3:1 ratio and another group which is homozygous $\mathrm{HH}$. The second group occurs because either homozygous $\mathrm{HH} \mathrm{F}_{\mathbf{2}}$ plants were contained among the class III heterozygotes, or a proportion of the class III $\mathrm{F}_{2}$ heterozygotes change from $\mathrm{Hh}$ to $\mathrm{HH}$. Studies on later generations described below show that the last interpretation is correct.

\section{3. $\mathrm{F}_{3}$ AND $\mathrm{F}_{4}$ GENERATIONS}

The $\mathrm{F}_{4}$ generation was grown to examine the behaviour of the genetic factors determining $\mathrm{H}-\mathrm{h}$ in $\mathrm{F}_{3}$ and $\mathrm{F}_{4}$. For this and later generations descendants of the $F_{3}$ generation of Expt. 2 only were grown. In this experiment the $12 \mathrm{~F}_{3}$ families gave a mean ratio of $\mathrm{H}: \mathrm{h}$ of $6 \cdot 8: 1$; it contained 4 non-segregating families and the $\mathrm{H}: \mathrm{h}$ ratio of the remaining 8 segregating families was not significantly different from $3: 1$. It therefore conforms to the average pattern of the three $\mathrm{F}_{3}$ experiments.

An $\mathrm{F}_{4}$ family of up to 10 plants was grown from a capsule taken from each of 80 of the $89 \mathrm{~F}_{3} \mathrm{H}$ plants of Expt. 2 (table 3). Twenty-eight of these were from the $31 \mathrm{H}$ plants in the four non-segregating families; the remaining 52 were from among the $58 \mathrm{H}$ plants in the eight segregating families (table 3). Each $\mathrm{F}_{4}$ family was grown in a separate pot in John Innes compost from November to March in a heated greenhouse with supplementary lighting.

Twenty-seven of the $28 \mathrm{~F}_{4}$ families from non-segregating $\mathrm{F}_{3}$ families showed no segregation (table 3 ). The single segregating family gave a ratio of $\mathrm{H}: \mathrm{h}$ of $9: 1$ and was from one of eight $\mathrm{H}$ plants in the non-segregating $\mathrm{L} \times \mathrm{S} \mathrm{F}_{3}$ family. None of the other seven $\mathrm{H}$ plants gave segregating $\mathrm{F}_{4}$ families. The probability of its occurrence being due to heterozygosity of the $\mathrm{F}_{2}$ grandparent and mendelian segregation thereafter is very small, and it must be due to a different type of event than those under consideration. Excepting this single $h$ h plant, the $28 \mathrm{~F}_{4}$ families are members of true breeding homozygous $\mathrm{HH}$ lines.

The $\mathrm{H}$ parent plants of the $52 \mathrm{~F}_{4}$ families from segregating $\mathrm{F}_{3}$ families should be $\mathrm{HH}: \mathrm{Hh}$ in a ratio of $1: 2$ and therefore give non-segregating to segregating families in the $F_{4}$ in a ratio of $1: 2$. The ratio is 29:23 (table 3). The probability of a selfed heterozygous plant giving no homozygous recessives in a family of ten plants is $(0 \cdot 75)^{10}$, approximately $5 \cdot 7$ per cent., so that 23 segregating families must represent 94.7 per cent. of the true frequency of segregating families, giving corrected frequencies of nonsegregating and segregating $\mathrm{F}_{4}$ families of $27 \cdot 7$ and $24 \cdot 3$. Rounding off in the direction of the expected $1: 2$ ratio this gives a ratio of $27: 25$, which deviates significantly $(P<0.01)$ from a $1: 2$ ratio. These $F_{4}$ families were from segregating $\mathrm{F}_{3}$ families and there is no possibility of $\mathrm{HH}$ homozygotes being among their $F_{2}$ parents. Therefore the disproportionate number of non-segregating $\mathrm{F}_{4}$ families must have been due to a change of $\mathrm{Hh}$ (or hh) to $\mathrm{HH}$. It is also reasonable to conclude that the disproportionate number of non-segregating $\mathrm{HH}$ families in the $\mathrm{F}_{3}$ was due to a similar cause, viz., a change of $\mathrm{Hh} \rightarrow \mathrm{HH}$, rather than to the inclusion of $\mathrm{HH}$ plants with low hair number among the $\mathrm{F}_{\mathbf{2}}$ class III heterozygotes, for which there is no supporting evidence elsewhere.

In table 5 the $\mathrm{F}_{4}$ families have been split into the two sets of crosses, $\mathrm{L} \times \mathrm{Pl}, \mathrm{Pl} \times \mathrm{L}$, and $\mathrm{L} \times \mathrm{S}, \mathrm{S} \times \mathrm{L}$, and interpreted in terms of genotypic 
frequencies in the $\mathrm{F}_{3}$ segregating families. Although no $\mathrm{F}_{4}$ families were grown from $F_{3}$ hh plants, these are expected to give all hh $F_{4}$ families and are included to complete the $\mathrm{F}_{3}$ generation. Since 52 out of a total of $58 \mathrm{H}$ plants were used as parents the $13 \mathrm{hh}$ plants should be reduced proportionately to 12 , approximating to 6.5 and 5.5 in the two sets of crosses respectively but the adjustments would make no difference to the overall conclusions.

Table 5 shows that there is no deviation from a $1: 2: 1$ ratio in the $\mathrm{Pl} \times \mathrm{S}$ and $\mathrm{S} \times \mathrm{Pl}$ crosses, only in the $\mathrm{L} \times \mathrm{S}$ and $\mathrm{S} \times \mathrm{L}$ crosses which now separated out reveal a ratio approximating closely to $2: 1: 1$; in both sets of crosses the $\mathrm{H}: \mathrm{h}$ ratio is close to $3: 1$ and is a reflection of the $3: 1$ ratio given by the segregating families in $F_{3}$. Table 3 shows that the overall ratio of $\mathrm{H}: \mathrm{h}$ among the segregating $F_{4}$ families is $159: 59$, which agrees with a $3: 1$ ratio. Therefore, apart from the difference between the two sets of crosses in $F_{3}$,

TABle 5

Frequencies of $\mathrm{HH}$ and Hh plants in segregating $F_{3}$ families interpreted from the numbers of segregating and non-segreg. ating families in $F_{4}$. The number of $h h F_{3}$ plants in the segregating $F_{8}$ families are given

\begin{tabular}{|c|c|c|c|}
\hline & & s ger & \\
\hline & $\mathrm{HH}$ & $\mathrm{Hh}$ & $\mathrm{hh}$ \\
\hline Unadjusted & 29 & 23 & 13 \\
\hline Adjusted & 27 & 25 & 13 \\
\hline $\left.\begin{array}{l}\mathrm{Pl} \times \mathrm{S} \\
\mathrm{S} \times \mathrm{Pl}\end{array}\right\}$ & 7 & 17 & 7 \\
\hline $\left.\begin{array}{l}\mathrm{L} \times \mathrm{S} \\
\mathrm{S} \times \mathrm{L}\end{array}\right\}$ & 20 & 8 & 6 \\
\hline
\end{tabular}

the $F_{3}$ repeats the pattern of the $F_{2}$ in giving rise to an excess of nonsegregating families in the next generation but within any one generation a normal 3:1 segregation occurs among the segregating families.

\section{4. $\mathrm{F}_{4}$ AND $\mathrm{F}_{5}$ GENERATIONS}

One hundred and forty-eight $F_{5}$ families of up to 10 plants each were grown out of doors in pots from April to August in compost without John Innes fertiliser or lime. Firty-five families were from hh plants (one capsule from each) from non-segregating $\mathrm{hh} \mathrm{F}_{4}$ families taken at random over the four crosses. Fifty-five families were from $\mathrm{HH}$ plants from non-segregating $\mathrm{HH} \mathrm{F}_{4}$ families taken at random over the $\mathrm{L} \times \mathrm{S}$ and $\mathrm{S} \times \mathrm{L}$ crosses. Thirtyeight families were from $\mathrm{H}$ plants from segregating $\mathrm{F}_{4}$ families taken at random over $\mathrm{L} \times \mathrm{S}$ and $\mathrm{S} \times \mathrm{L}$ crosses.

The $110 \mathrm{~F}_{5}$ families from non-segregating $\mathrm{HH}$ and $\mathrm{hh} \mathrm{F}_{4}$ families bred true, confirming the relative stability of this locus when homozygous. The $38 \mathrm{~F}_{5}$ families from $\mathrm{H}$ plants in segregating $\mathrm{F}_{4}$ families consisted of 10 nonsegregating families and 28 segregating families, which do not deviate significantly from a 1:2 ratio. Within the $F_{5}$ segregating families there was an overall ratio of $H: h$ of $176: 59$, which is an almost exact $3: 1$ ratio. Therefore $H$-h segregates normally in $F_{4}$ families; unlike the $F_{2}$ and $F_{3}$ there is no evidence of change of $\mathrm{Hh}$ to $\mathrm{HH}$, or of $\mathrm{Hh}$ to hh. 


\section{Discussion}

The overall frequencies of homozygotes and class I, II and III heterozygotes in the $F_{2}$, grown in the field from April to September, of reciprocal crosses between $\mathrm{L}$ and $\mathrm{Pl}$, and between $\mathrm{L}$ and S (Durrant and Nicholas, 1970) are given in table 6 . The segregation of $\mathrm{H}: \mathrm{h}$ deviates significantly from a 3:1 ratio with excess h plants, and the homozygotes $\mathrm{HH}$ and $\mathrm{hh}$ deviate significantly from a $1: 1$ ratio with excess hh plants. Genetic instability in plant weight occurs in the $\mathrm{F}_{1}$ of $\mathrm{L} \times \mathrm{S}$ and $\mathrm{S} \times \mathrm{L}$ crosses (Durrant, $1962 b$; Durrant and Tyson, 1965), and it is likely that major instability at the $h$ locus also occurs in the first instance in $\mathrm{F}_{1} \mathrm{Hh}$ heterozygotes to give the non-mendelian segregations and three heterozygous classes in the $F_{2}$ shown in table 6 . It is possible, but unlikely from the present observations, that the state of the $\mathrm{Hh}$ heterozygote is uniform over all $\mathrm{F}_{1}$ plants, instability developing during the growth of the $F_{2}$ plants. This could be resolved by examining descendants of individual $F_{1}$ plants. If instability occurs in the $F_{1}$, the distribution in table 6 will be determined by the pattern of instability among the $F_{1}$ plants and their contributions to the seed samples used for $F_{2}$. The instability is modified by the genotrophic background, i.e. $\mathrm{Pl} \times \mathrm{S}$,

TABLE 6

Class frequencies in $F_{2}$ summed over all crosses

(Durrant and Nicholas, 1971)

$\begin{array}{llccc}\text { HH } & \text { III } & \text { II } & \text { I } & \text { hh } \\ 167 & 147 & 204 & 81 & 243\end{array}$

$\mathrm{S} \times \mathrm{Pl}$ compared with $\mathrm{L} \times \mathrm{S}, \mathrm{S} \times \mathrm{L}$ and the environment in which the parents and $F_{1}$ plants are grown (Durrant and Nicholas, 1970), but there are no differences between reciprocal crosses.

$F_{2}$ class III heterozygotes give an excess of non-segregating $F_{3}$ families; there are no differences between the two types of crosses, nor between reciprocals, and the $F_{3}$ families which segergate do so in a 3:1 ratio. There must therefore be some plants among the $\mathrm{F}_{2}$ class III heterozygotes which have a capacity, or potential, for the change $\mathrm{Hh} \rightarrow \mathrm{HH}$, but the change in any one plant is not realised until later in development after its hair number has been determined. The $\mathrm{F}_{2}$ class III heterozygotes which do not have this potential give a normal $3: 1$ ratio in the $F_{3}$. If all $F_{2}$ class III heterozygotes had the same but moderate potential all $\mathrm{F}_{3}$ families would give, within the limits of sampling error, uniform excess of $\mathrm{H}$ plants, which is not the case. Assessed over all crosses and experiments (table 3), 14 out of 38 ( 37 per cent.) $\mathrm{F}_{2}$ class III heterozygotes have the $\mathrm{Hh} \rightarrow \mathrm{HH}$ potential (Expt. 2 by itself, 33 per cent.).

The $\mathrm{F}_{4}$ generation shows however that among the $\mathrm{F}_{3}$ families descended from the remaining two-thirds of $\mathrm{F}_{2}$ plants apparently without the $\mathrm{Hh} \rightarrow \mathrm{HH}$ potential there are $\mathrm{Hh}$ plants in the $\mathrm{L} \times \mathrm{S}, \mathrm{S} \times \mathrm{L}$ crosses, but not in $\mathrm{Pl} \times \mathrm{S}$, $\mathrm{S} \times \mathrm{Pl}$, which give non-segregating $\mathrm{F}_{4}$ families. These must have since acquired the $\mathrm{Hh} \rightarrow \mathrm{HH}$ potential, or only now is it realised. Here a ratio of $\mathrm{HH}: \mathrm{Hh}: \mathrm{hh}$ among the $\mathrm{F}_{3}$ heterozygotes of $2: 1: 1$ indicates that half the $\mathrm{HH}$ plants arise from the change $\mathrm{Hh} \rightarrow \mathrm{HH}$, that is approximately 10 
out of 18 heterozygotes ( 57 per cent.) changed to $\mathrm{HH}$. In the $\mathrm{F}_{4}$ no changes are found. The $\mathrm{Hh} \rightarrow \mathrm{HH}$ potential first disappears in the $\mathrm{F}_{3}$ of the $\mathrm{L} \times \mathrm{Pl}$, $\mathrm{Pl} \times \mathrm{L}$ crosses, and one generation later in the $\mathrm{F}_{4}$ of the $\mathrm{L} \times \mathrm{S}, \mathrm{S} \times \mathrm{L}$ crosses.

Summarising, when the two alleles are brought together in the $F_{1}$ with their associated genotrophic backgrounds, the $\mathrm{Hh}$ heterozygote is unstable and changes may occur in either direction, $\mathrm{H} \rightarrow \mathrm{h}$ or $\mathrm{h} \rightarrow \mathrm{H}$. In the present environments there was an excess of hh homozygotes in the $\mathrm{F}_{2}$ (table 6 ) so that in the $F_{1}$ generation the change was predominantly, or entirely, $\mathrm{H} \rightarrow \mathrm{h}$. The three heterozygote classes in the $\mathrm{F}_{2}$ reflect further levels of instability and in selecting class III Hh plants, with the highest hair numbers, there is selection also for plants with a high $\mathrm{Hh} \rightarrow \mathrm{HH}$ potential. Only some $F_{2}$ plants have this potential in so far as it leads to an overt and immediate change of $\mathrm{Hh} \rightarrow \mathrm{HH}$ by the next generation. In the $\mathrm{L} \times \mathrm{S}$, $\mathrm{S} \times \mathrm{L}$ crosses a further set of $\mathrm{Hh}$ plants in the $\mathrm{F}_{3}$ show this potential. Thereafter none is found.

The fade-out could be due to four reasons. First, the instability of the $\mathrm{Hh}$ heterozygote is not a function of the locus, i.e. a unit cistron, but a function of associated elements closely linked to the locus or elsewhere on the chromosomes, the apparent stabilisation of the locus in later generations being due to the stabilisation of the other elements following the initial instability brought about by heterozygosity. Second, the H-h locus may be compounded of a number of repeated segments, differing in number between the two alleles and in the different genotrophs, and interacting in the heterozygote to produce repeated sequences with different numbers again, eventually stabilising and rationalising into stable $H$ and $h$ alleles once more. If the repeated segments are not the gene itself but in one way or another influence its activity, they may be the associated elements of the first interpretation. Third, no classification of heterozygote hair number was carried out after $\mathrm{F}_{2}$ and consequently there was no further selection for class III. Hence the initial impetus and potential for $\mathrm{Hh} \rightarrow \mathrm{HH}$ is gradually lost, and the data contain once more three heterozygous classes; one would, however, have expected the analysis to have picked up changes in both directions. Fourth, the $\mathrm{Hh} \rightarrow \mathrm{HH}$ potential is influenced by the different environments in which the generations are grown. The differences between the two sets of crosses, $\mathrm{Pl} \times \mathrm{S}, \mathrm{S} \times \mathrm{Pl}$ compared with $\mathrm{L} \times \mathrm{S}, \mathrm{S} \times \mathrm{L}$ in the $F_{2}$ ratios, and generation in which stabilisation, or apparent stabilisation, occurs, are compatible with these interpretations.

The instability of the heterozygote compared with the homozygote parallels, as mentioned elsewhere, the instability of mating type heterozygotes in Tetrahymena (Nanney and Caughey, 1955) and, particularly with regard to the $\mathrm{H}$-h locus, to paramutation in maize (Brink, 1960), the differences between the two possibly being only a matter of degree. All $R^{r}$ alleles paramutate when heterozygous with $R^{s t}$ whereas only a proportion of $\mathrm{h}$ change to $\mathrm{H}$, or vice versa depending on conditions, but if the heterozygous $\mathrm{Hh}$ classes are taken into account probably all alleles change in activity, and varying degrees of paramutation can be obtained at the $R$ locus (Mikula, 1961). Heritable changes in plant height and flowering time have been induced in a highly inbred variety of Nicotiana rustica (Hill, 1967). Crossing between the induced types gives $\mathbf{F}_{\mathbf{1}}$ instability (Perkins, Eglington and Jinks, 1971) similar to that given by the induced plant weight changes in flax. It seems, therefore, that environmentally 
induced changes, including those at the $h$ locus, which are stable in themselves, may be generally unstable in the heterozygous state.

\section{REFERENCES}

BRINK, R. A. 1960. Paramutation and chromosome organisation. Quart. Rev. Biol., 35, 120-137.

DURRANT, A. 1962a. The environmental induction of heritable change in Linum. Heredity, $17,27-61$.

DURRANT, A. 1962b. Induction, reversion and epitrophism in flax. Nature, 204, 1302-1304.

DURRANT, A. 1971. Induction and growth of flax genotrophs. Heredity, 27, 277-298.

DURRANT, A., AND NICHOLAS, D. B. 1970. An unstable gene in flax. Heredity, 25, 513-527.

DURRANT, A., AND TYSON, H. 1964. A diallel cross of genotypes and genotrophs of Linum. Heredity, 19, 207-227.

EVANS, G. M. 1968. Nuclear changes in flax. Heredity, 23, 25-38.

EVANS, G. M., DURRANT, A., AND REES, H. 1966. Associated nuclear changes in the induction of flax genotrophs. Nature, 212, 697-699.

HILL, J. 1967. The environmental induction of heritable change in Nicotiana rustica: parental and selection lines. Genetics, 55, 735-754.

mikULA, в, с. 1961. Progressive conversion of $R$-locus expression in maize. Proc. Nat. Acad. Sci. U.S., 47, 566-571.

NANNEY, D. L., AND CAUGheY, P. A. 1955. An unstable nuclear condition in Tetrahymena piriformis. Genetics, 40, 388-398.

PERKINS, M. J., EGLINGTON, E. G., AND JINKS, J. L. 1971. The nature of the inheritance of permanently induced changes in Nicotiana rustica. Heredity, 27, 441-457. 